Media Farmasi p.issn 0216-2083 e.issn 2622-0962 Vol. XV No. 1, April 2019,

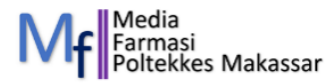

\title{
KADAR CEMARAN LOGAM TIMBAL (Pb) DALAM MADU YANG BEREDAR DI KOTA MAKASSAR
}

\author{
Tajuddin Abdullah ${ }^{1 *}$, Ratnasari Dewi \\ 1,2Jurusan Farmasi Poltekkes Kemenkes Makassar
}

${ }^{*}$ Koresponden : Tajuddin Abdullah, Email : tajuddin.abdullah@poltekkes-mks.ac.id

DOI: https://doi.org/10.32382/mf.v15i1.901

\section{ABSTRAK}

Penelitian ini bertujuan untuk mengetahui kadar cemaran logam timbal $(\mathrm{Pb})$ dalam madu yang beredar di kota Makassar dan menentukan kesesuaian kadar cemaran logam timbal $(\mathrm{Pb})$ dalam madu tersebut dengan persyaratan yang ditentukan (maksimal $1.0 \mathrm{mg} / \mathrm{kg}$ ). Madu mengandung banyak vitamin yang diperlukan oleh tubuh dan juga mengandung klorin untuk aktivitas tubuh. Madu juga dapat dijadikan sebagai antibiotik, dan berbagai obat dalam kesehatan. Dua sampel madu tidak bermerek yang dibeli dari beberapa pedagang di Kota Makassar dan madu yang bermerek yang dibeli di swalayan di Kota Makassar. Sampel di timbang sebanyak 1 gram lalu di tambahkan $15 \mathrm{ml} \mathrm{HNO}_{3}$, kemudian di panaskan di atas hot plate dengan suhu $100{ }^{0} \mathrm{C}$ hingga larutan berubah warna menjadi bening. Kemudian tiga sampel madu ini di uji kualitatif di tentukan berdasarkan serapan sampel yang dibandingkan dengan serapan kontrol dan menggunakan larutan $\mathrm{Pb}\left(\mathrm{NO}_{3}\right)_{2}$. Kemudian dilakukan uji kuantitatif menggunakan alat Spektrofotometri serapan atom. Dari ketiga sampel madu yang digunakan, berdasarkan hasil pengujian di atas yang telah dilakukan, ketiga sampel madu negatif tercemar logam timbal $(\mathrm{Pb})$

Kata kunci : madu, timbal( $\mathrm{Pb})$, spektrofotometri serapan atom, uji kualitatif, uji kuantitatif

\section{PENDAHULUAN}

Madu adalah cairan yang banyak mengandung zat gula dan rasanya sangat manis, banyak terdapat pada sarang lebah dan bunga. Madu memiliki banyak manfaat terutama untuk kesehatan tubuh. Madu mengandung banyak vitamin yang diperlukan oleh tubuh dan juga mengandung kalori untuk aktivitas tubuh. Madu juga dapat dijadikan sebagai antibiotik, dan berbagai obat dalam kesehatan.

Pengobatan dengan menggunakan madu telah dikenal orang Mesir kuno sejak 2.600 SM. Bangsa yunani, Romawi, dan China kuno sudah menggunakan madu sebagai antiseptik dalam mengobati luka. Walaupun sejak aband ke-19 peranan madu sebagai pemanis telah tergeser oleh kehadiran gula yang terbuat dari tebu, sampai sekarang madu masih dimanfaatkan dalam pembuatan kue dan aneka makanan lainnya. Oleh karena itu pemanfaatannya yang sangat luas maka madu harus bebas dari semua kontaminasi yang dapat merugikan manusia terutama logam berat.

Ada beberapa faktor-faktor yang menyebabkan madu murni tidak berkualitas, diantaranya yaittu Pengolahan pasca panen.Di antara sifat yang ada pada madu adalah korosif (melarutkan logam).Maka tidak dianjurkan menempatkan madu pada tempat yang terbuat dari logam. Hal tersebut akan sangat berpengaruh terhadap keberadaan cemaran logam dalam madu. Adapun sumber bahan pencemaran logam berat yaitu dari alam (air, tanah, dan udara), industri, dan sumber dari transportasi, selain itu sumber pencemaran berasal dari penggunaan insektisida, gas emisi kendaraan bermotor di lahan penanaman atau saat pendistribusian, air yang tercemar oleh logam yang mengalir pada lahan dan cara penyimpanannya dan alat-alat yang terbuat dari jenis logam lainnya. Karena timbal tidak ditemukan bebas dialam akan tetapi biasanya ditemukan sebagai biji mineral bersama dengan logam lain misalnya seng, perak, dan tembaga.

Logam berat timbal $(\mathrm{Pb})$ dan tembaga $(\mathrm{Cu})$ apabila sudah melebihi batas yang ditentukan berbahaya bagi kehidupan dan dapat menyebabkan penyakit karena bersifat toksik. Apabila logam-logam 
tersebut masuk ke dalam tubuh lewat makanan dapat menganggu sistem syaraf, kerusakan otak, kelumpuhan, pertumbuhan terhambat, kerusakan ginjal, kerapuhan tulang dan kerusakan DNA atau kanker (Agustina, 2010).

Oleh karena itu pemerintah telah mengaturbatas maksimum cemaran logam dalam madu berdasarkan SNI 013545 tahun 2004 yaitu untuk timbal $(\mathrm{Pb})$ adalah 1,0 mg/kg. Berdasarkan latar belakang tersebut perlu dilakukan penelitian logam berat $\mathrm{Pb}$ dalam madu karena jika melebihi batas yang diperbolehkan berdampak terhadap kesehatan manusia yang mengkonsumsinya. Rumusan masalah pada peneltian ini adalah berapa kadar cemaran logam timbal $(\mathrm{Pb})$ dalam madu yang beredar di kota Makassar? Dan apakah kadar cemaran logam timbal $(\mathrm{Pb})$ dalam madu tersebut memenuhi standar SNI ?. Tujuan Penelitian ini adalah untuk mengetahui kadar cemaran logam timbal $(\mathrm{Pb})$ dalam madu yang beredar di kota Makassar dan menentukan kesesuaian kadar cemaran logam timbal $\mathrm{Pb})$ dalam madu tersebut dengan persyaratan yang ditentukan (maksimal $1.0 \mathrm{mg} / \mathrm{kg})$.

\section{METODE PENELITIAN Jenis penelitian}

Jenis penelitian ini adalah penelitian observasi laboratorium yaitu untuk mengetahui kadar cemaran logam timbal $(\mathrm{Pb})$ dalam madu yang beredar di Kota makassar. Penelitian ini telah di laksanakan di laboratorium Kesehatan Kota Makassar pada bulan Mei 2018

\section{Alat dan Bahan}

Alat yag digunakan adalah beaker gelas, Corong gelas, Gelas arloji, Hot plate, Labu ukur, Neraca analitik, Pipit volum, Sendok tanduk dan Spektrofotometer Serapan Atom. Bahan yang digunakan adalah air suling, NHO3 peka, Kertas saring, Beberapa madu (madu bermerek dan madu tidak bermerek), $\mathrm{Pb}$ (NO3)2

\section{Pengambilan sampel}

Sampel berupa madu tidak bermerek yang dibeli dari beberapa pedagang di Kota Makassar dan madu yang bermerek yang dibeli di swalayan di Kota Makassar

\section{Pembuatan larutan sampel}

Sampel di timbang sebanyak 1 gram lalu masukkan ke dalam beaker gelas di tambahkan $15 \mathrm{ml} \mathrm{HNO}_{3} 0,1 \mathrm{~N}$ kemudian dipanaskan di atas hot plate dengan suhu 100 $\mathrm{C}$ hingga berubah warna menjadi bening, lalu di dinginkan. Setelah dingin larutan di saring ke dalam labu ukur $50 \mathrm{ml}$, kemudian di encerkan dengan $\mathrm{HNO}_{3} \quad 0,1 \mathrm{~N}$ sampai tanda batas.

\section{Analisis kualitatif}

Larutan sampel di masukkan ke dalam tabung reaksi dan larutan kontrol di masukkan ke dalam tabung reaksi. Kemudian kedua larutan tersebut di masukkan ke dalam alat spektrofotometri serapan atom untuk di ukur serapannya.

\section{Analisis kuantitatif}

a. Pembuatan kurva baku

Dibuat larutan masing-masing dengan cara mengukur saksama masing 5,0; 10,$0 ; 15,0 ; 20,0$; dan 25,0 ml larutan baku. Kemudian masing-masing dimasukkan ke dalam labu ukur 100 $\mathrm{ml}$, dicukupkan volumenya dengan HNO3 0,1 N hingga tanda. Larutan dikocok hingga homogen, kemudian diukur serapan atom menggunakan lampu katoda $\mathrm{Pb}$ pada $\square 283,3 \square \mathrm{m}$.

b. Pengukuran serapan sampel dengan metode Spektrofotometri Serapan Atom. Larutan sampel dimasukkan ke dalam alat pengukuran kemudian di ukur serapannya dengan menggunakan alat Spektrofotometri serapan atom pada panjang gelombang 283,3 $\square \mathrm{m}$ menggunakan lampu katoda $\mathrm{Pb}$.

\section{Pengolahan Data}

Data hasil pengukuran dihitung menggunakan persamaan garis regresi yang dihasilkan dari pengukuran larutan baku pada pembuatan kurva baku.

Dari persamaan kurva yang di peroleh : $\mathbf{y}=\mathbf{a}$ $+\mathbf{b x}$

Lalu Kadar timbal $(\mathrm{Pb})$ di ditentukan

HASIL

Penelitian ini dilakukan untuk menentukan adanya logam $\mathrm{Pb}$ dalam sampel 
Madu, selanjutnya ditentukan kadarnya dan di bandingkan dengan persyaratan yang di tentukan dan memenuhi standar SNI. Instrumen yang digunakan pada penelitian ini adalah spektrofotometri serapan atom. Analisis kualitatif dilakukan untuk menentukan adanya logam $\mathrm{Pb}$ pada sampel madu, data hasil uji tersebut tersaji dalam Tabel 1. Berdasarkan Tabel 1, menunjukkan bahwa 3 sampel negative mengandung $\mathrm{Pb}$. Uji kuantitatif untuk menentukan kadar logam $\mathrm{Pb}$ pada sampel madu, data hasil uji tersebut tersaji dalam Tabel 2. Berdasarkan Tabel 2 menunjukkan bahwa 3 sampel madu negatif mengandung $\mathrm{Pb}$.

\section{PEMBAHASAN}

Pada penelitian ini dilakukan analisis kandungan logam timbal dengan menggunakan metode spektrofotometri serapan atom. Adapun sampel yang di gunakan dalam penelitian ini adalah madu. Sampel di timbang sebanyak 1 gram lalu masukkan ke dalam beaker gelas di tambahkan $15 \mathrm{ml} \mathrm{HNO}_{3} \quad 0,1 \mathrm{~N}$ kemudian dipanaskan di atas hot plate dengan suhu 100C hingga berubah warna menjadi bening, lalu di dinginkan. Setelah dingin larutan di saring ke dalam labu ukur $50 \mathrm{ml}$, kemudian di encerkan dengan $\mathrm{HNO}_{3} \quad 0,1 \mathrm{~N}$ sampai tanda batas, kemudian larutan tersebut di masukkan ke dalam tabung dan di masukkan ke dalam alat spektrofotometri serapan atom untuk di ukur serapannya. Hasil uji kualitatif ditentukan berdasarkan serapan sampel yang dibandingkan dengan serapan kontrol. Sebagai kontrol negatif (blanko) digunakan larutan tanpa $\mathrm{Pb}$ sedangkan kontrol positif digunakan larutan $\mathrm{Pb} \quad 1 \mathrm{ppm}$. Sampel dikatakan positif jika serapan sampel lebih besar dari serapan blanko, hal ini disebabkan oleh persepsi bahwa jika sampel memberikan serapan (lebih besar dari blanko) maka sampel tersebut mengandung $\mathrm{Pb}$. Kelompok kontrol positif untuk menunjukkan bahwa jika larutan mengandung $\mathrm{Pb} 1 \mathrm{ppm}$ maka serapannya adalah sebesar serapan terukur $(0,0084)$, sekalipun serapan sampel lebih kecil dari serapan kontrol positif, ini menunjukkan bahwa sampel positif mengandung $\mathrm{Pb}$ yang konsentrasinya kurang dari 1 ppm.

Uji kualitatif untuk mendetiksi ada logam yang terkandung dalam sampel madu. Dan hasil uji kualitatif ini menujukkan bahwa 3 sampel negatif mengandung logam $\mathrm{Pb}$ (karena serapan larutan sampel kurang dari serapan pembanding/kontrol negatif). Uji kuantitatif di lakukan untuk mengetahui kadar $\mathrm{Pb}$ dalam sampel madu. Dan hasil uji kuantitatif dengan menggunakan alat Spektrofotometri Serapan Atom menunjukkan bahwa 3 sampel tersebut negatif mengandung logam timbal $(\mathrm{Pb})$.Hasil penelitian diatas menunjukkan bahwa ketiga sampel madu yang di gunakan terbebas dari cemaran logam timbal $(\mathrm{Pb})$. Dibandingkan dengan penelitian sebelumnya yang di lakukan oleh mahasiswa di Medan menunjukkan sampel madu di gunakan mengandung logam timbal sebesar $0,35+0,03 \mathrm{mg} / \mathrm{kg}$, hasil tersebut masih berada di bawah batas maksimumnya yaitu $1,0 \mathrm{mg} / \mathrm{kg}$ sesuai dengan Standar Mutu Madu berdasarkan SNI 01-3545-2004

\section{KESIMPULAN}

Berdasarkan hasil penelitian yang telah dilakukan, maka di peroleh kesimpulan sebagai berikut :

1. Tiga sampel madu dinyatakan negatif tercemar logam timbal $(\mathrm{Pb})$

2. Kadar logam timbal $(\mathrm{Pb})$ pada sampel madu A -1,6764 mg/kg, sampel madu B $-1,0528 \mathrm{mg} / \mathrm{kg}$, dan sampel madu C $1,3582 \mathrm{mg} / \mathrm{kg}$.

3. Kadar cemaran timbal dari ke 3 sampel Madu tersebut memenuhi syarat yang telah ditentukan yaitu 1 ppm (1,0 $\mathrm{mg} / \mathrm{kg}$ )

\section{SARAN}

Berdasarkan hasil penelitian dan pembahasan penelitian di atas maka di sarankan :

1. Untuk dilakukan penelitian lanjutan cemaran logam berat dari madu

2. Di lakukan pengujian kadar sukrosa dari madu

\section{DAFTAR PUTAKA}

Harmita, 2015, Analisis Fisikokimia potensiometri \& Spektroskopi, kedokteran, EGC, Jakarta

Anomin http://pengolahanairbersih.blogspot.co.id/2015/09/baha ya-pencemaran- air-oleh-logam- 
berat.html di akses pada tanggal 24

Januari 2017

Anonim,http://yonomadu.blogspot.co.id/201 0/12/madu-sni.html?m=1. Di akses pada tanggal 11 Januari 2017 SpektrofotometriSerapanAtom".rep ository.usu.ac.id/bitstream/1234567 89/14319/1/09E02796.pdf. Di akses pada tanggal 05 July 2017

Tabel 1. Analisa Kualitatif

\begin{tabular}{ccc}
\hline Sampel & Replikasi & Kadar $(\mathrm{mg} / \mathrm{kg})$ \\
\hline A & 1 & 0 \\
B & 1 & 0 \\
C & 1 & 0 \\
\hline
\end{tabular}

Tabel 2. Analisa Kuantitatif

\begin{tabular}{lccc}
\hline No & Identifikasi & Serapan & Kesimpulan \\
& & & \\
\hline \multirow{2}{*}{ Kontrol negatif } & 0,0000 & - \\
& Kontrok positif & 0,0084 & + \\
\hline \multirow{2}{*}{2} & Sampel A & $-0,0110$ & - \\
& Sampel B & $-0,0072$ & - \\
& Sampel C & $-0,0089$ & - \\
\hline
\end{tabular}

